\title{
SURVIVABILITY OF ENCAPSULATED LACTOBACILLI IN HIGH ACID FOODS
}

\author{
C.S.C. THAM ${ }^{\mathrm{a}}$ K.K. PEH ${ }^{\mathrm{b}}$ and M.T. Liong ${ }^{\mathrm{a} *}$

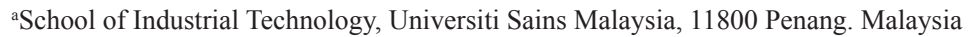

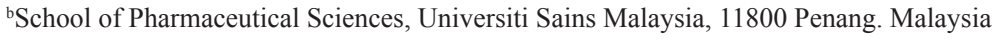

(Received: 2 June 2013; accepted: 17 July 2013)

\begin{abstract}
This study aimed to evaluate the survivability of lactobacilli cells encapsulated in calcium alginate beads coated with methacrylic acid copolymers (MAc) in high acidic foods (orange juice and mayonnaise). Lactobacilli survived well at low temperature $\left(4^{\circ} \mathrm{C}\right)$ for $6 \mathrm{wk}$ in orange juice, $4 \mathrm{wk}$ in heat-treated orange juice, $12 \mathrm{wk}$ in mayonnaise, and 8 wk in heat-treated mayonnaise $(\mathrm{P}<0.05)$, without affecting the acidity of orange juice and mayonnaise during storage. FTIR spectra showed that the characteristic peaks of calcium alginate and MAc were not altered, designating no high affinity interaction between calcium alginate and MAc. DSC of MAc-coated alginate beads indicated an increased in melting temperature, demonstrating improvement in molecular orientation in the MAc-coated alginate beads compared to the control. Sensory evaluation revealed that panellists could detect the presence of MAc-coated alginate beads, leading to a lower acceptance score.
\end{abstract}

Keywords: methacrylic acid copolymers, calcium alginate, FTIR, DSC, lactobacilli

Many strains of Lactobacillus have been associated with health and nutritional benefits for the maintenance and proliferation of healthy intestinal microflora. (Liong et al., 2007), attributed to their abilities to produce acids and at the same time, surviving in acidic environment (LIONG \& SHAH, 2005). High acidic foods, such as fruit juices (pH 2.5 and 3.7) and mayonnaise ( $\mathrm{pH} 4.1$ ), pose a challenge for the incorporation of lactobacilli due to the growth inhibiting properties of the acidic environment. Hence, encapsulation has been applied to maintain the viability of cells in such foods (GIRHEPUNJE et al., 2010).

Alginate has been greatly applied in food products, also as an encapsulant. Unfortunately, calcium alginate gel is insufficient to provide protection under acidic conditions (Sultana et al., 2000), due to porosity of the calcium alginate matrix leading to acid penetration from the media to the interior of the matrix. An additional coating of the calcium alginate beads is needed to enhance protection. Methacrylic acid copolymer is a $\mathrm{pH}$-dependant polymer containing carboxyl groups that helps to protect lactobacilli against varying $\mathrm{pH}$ levels during transit in the gastrointestinal tract and provides controlled release at $\mathrm{pH}$-specific sites (THAM et al., 2014).

This study is the continuation of the work from our previous study (THAм et al., 2014), thus it is aimed to further evaluate the survivability of lactobacilli during storage in high acidic foods and to study potential interactions between MAc and calcium alginate using Fourier Transform Infrared Spectroscopy (FTIR) and Differential Scanning Calorimetry (DSC). The present study would also investigate the acceptability of orange juice and mayonnaise containing MAc-coated alginate beads by panellists through sensory evaluations.

\footnotetext{
* To whom correspondence should be addressed.

Phone: +604 653 2114; fax: +604657 3678; e-mail: mintze.liong@usm.my
} 


\section{Materials and methods}

\subsection{Bacterial cultures and encapsulation}

Lactobacillus casei BT 1268 was obtained from the Culture Collection Centre of the School of Industrial Technology, Universiti Sains Malaysia (Penang, Malaysia) and was propagated, maintained, and encapsulated as previously described (Тнам et al., 2014).

\subsection{Fourier transform infrared spectroscopy (FT-IR)}

The spectra of blank calcium alginate beads, vacuum-dried MAc powder, and MAc-coated alginate beads were determined by the $\mathrm{KBr}$ pellet method using a Thermo Scientific NicoletiS10 (Thermo Scientific Nicolet, Madison, WI). The dried matrices were vacuum dried at $40{ }^{\circ} \mathrm{C}$ for 2 days and then ground with a grinder into a fine powder (Moustafine et al., 2010). Two mg of each sample was mixed with dry $\mathrm{KBr}$ and then compressed into pellets. The samples were then analyzed with a scanning range of $4000-500 \mathrm{~cm}^{-1}$.

\subsection{Differential scanning calorimetry (DSC)}

The analysis of blank calcium alginate beads, vacuum-dried MAc powder, and MAc-coated alginate beads were scanned in the range of $30-430^{\circ} \mathrm{C}$, using a Perkin Elmer DSC 6 (PerkinElmer, Waltham, MA) at the heating rate of $10{ }^{\circ} \mathrm{C} \mathrm{min}^{-1}$ in a nitrogen atmosphere. Two $\mathrm{mg}$ of each sample was accurately weighed into individual aluminium pans and heated.

\subsection{Sensory evaluation}

Acceptability was studied with 100 (62 female, 38 male) untrained panellists using controls (blank orange juice or blank mayonnaise) and samples (orange juice or mayonnaise containing beads as prepared in Section 1.1). Prior to sensory evaluation, controls and samples were refrigerated, randomly coded, and served together with white bread to panellists seated separately in sensory booths. Comparisons were made for appearance, aroma, texture, graininess, sourness, mouthfeel, aftertaste, and overall acceptability at a 7-point hedonic scale where $1=$ like very much and $7=$ dislike very much.

\subsection{Storage and heat processing stability}

Commercially available orange juice (with no added preservatives) was used for all experiments. One hundred g of beads (as prepared in Section 1.1) was added into $900 \mathrm{ml}$ of orange juice, followed by pasteurization (high temperature short time) at $94{ }^{\circ} \mathrm{C}$ for $26 \mathrm{~s}$ and cooling $\left(0^{\circ} \mathrm{C}\right)$ (WALKLING-Ribeiro et al., 2009). Orange juice not containing any beads but treated the same way was used as control. Mayonnaise was prepared as previously described by KhaliL and Mansour (1998), with the addition of beads (100 g) to $900 \mathrm{~g}$ of the mayonnaise. The mixture was heated at $70{ }^{\circ} \mathrm{C}$ for $10 \mathrm{~min}$ and cooled $\left(0{ }^{\circ} \mathrm{C}\right)$. Mayonnaise not containing beads but prepared the same way was used as control.

Samples were stored at $4{ }^{\circ} \mathrm{C}$ and $27^{\circ} \mathrm{C}$ for $12 \mathrm{wk}$, sampled every $2 \mathrm{wk}$, washed with saline solution $(0.9 \%, \mathrm{w} / \mathrm{v})$, serially diluted, plated onto sterile MRS agar supplemented with L-cysteine hydrochloride $(0.15 \%, \mathrm{w} / \mathrm{v})$, and incubated at $37{ }^{\circ} \mathrm{C}$ for $48 \mathrm{~h}$. pH changes of samples were also analysed every $2 \mathrm{wk}$. 


\subsection{Statistical analysis}

Data analysis was carried out with SPSS Inc. software (version 14.0; SPSS Inc., Chicago, IL). The $t$-test and repeated measures ANOVA were used, with significance level at $\alpha=0.05$. Tukey's test was used to perform multiple comparisons between means. All data are presented as mean \pm standard error of means. All analyses were performed in triplicates, $n=3$.

\section{Results and discussion}

\subsection{Fourier transform infrared spectroscopy (FTIR) spectra}

The broad band between 3500 and $3000 \mathrm{~cm}^{-1}$ showed O-H stretching vibration from interand intramolecular hydrogen bonds, a typical characteristic of carboxylic groups (Fig. 1A, $1 \mathrm{~B}$ and $1 \mathrm{C}$ ), with a maximum band around $3500 \mathrm{~cm}^{-1}$ representing "free" hydroxyl stretch (RUfino \& Monteiro, 2003). The characteristic of calcium alginate spectra corresponded to $1635.27 \mathrm{~cm}^{-1}$ (COO), $1422.07 \mathrm{~cm}^{-1}(\mathrm{CH})$, and $1034.40 \mathrm{~cm}^{-1}$ (COC) (MLADENovsKa et al., 2007). The spectra at $1741.19 \mathrm{~cm}^{-1}$ was due to the vibration of carboxylic acids $(\mathrm{C}=\mathrm{O})$ in MAc. The deformation vibrations of $\mathrm{CH}_{3}$ and $\mathrm{CH}_{2}$ were also observed at $1451.99 \mathrm{~cm}^{-1}$ and $1386.32 \mathrm{~cm}^{-1}$ (Bianco et al., 2003; Rufino \& Monteiro, 2003). Our data showed absence of high affinity interaction between polymers in the mixture, with minimal chemical changes between the polymers during processing. This may be attributed to the anionic nature of both polymers that do not form any interactions (GuLREZ et al., 2011; SiBEKO et al., 2012).

\subsection{Differential scanning calorimetry (DSC) studies}

Maximum endothermic peaks corresponding to melting temperature were positioned at $171.369-176.215^{\circ} \mathrm{C}$ (Fig. 2A, 2B and 2C). Endothermic peaks are associated to loss of water linked to hydrophilic groups within the polymers (SARMENTo et al., 2006). Higher melting temperature was recorded for MAc-coated alginate beads $\left(176.215^{\circ} \mathrm{C}\right)$, while lower melting temperature were observed for blank calcium alginate beads and vacuum-dried MAc powder $\left(171.369{ }^{\circ} \mathrm{C}\right)$. A higher melting temperature indicates higher stability of complexes and crystallinity, in addition to a better orientation of molecules due to a higher energy requirement for the removal of residual water adsorbed onto beads. Thus, the addition of MAc layer improved the molecular orientation and crystallinity in beads (FuNG et al., 2011).

\subsection{Sensory evaluation}

The appearance, aroma, sourness, and aftertaste values between control and sample orange juices were similar (Table 1), indicating that the addition of MAc-coated alginate beads did not give "off-flavour" to the sample (KrasaeKoopt \& KitsaWAD, 2010). Texture, graininess, mouthfeel, and overall acceptability of orange juice containing MAc-coated alginate beads showed significant differences $(\mathrm{P}<0.05)$ as compared to the control. This may be due to the unfamiliarity of consumers with a "grainy" orange juice (KRASAekoopt \& Kitsawad, 2010), leading to reduced acceptability. A conventional orange juice contains soft pulps as compared to the hard MAc-coated alginate beads, hence the slight difference in texture in the mouth. Mayonnaise supplemented with MAc-coated alginate beads showed significant difference 

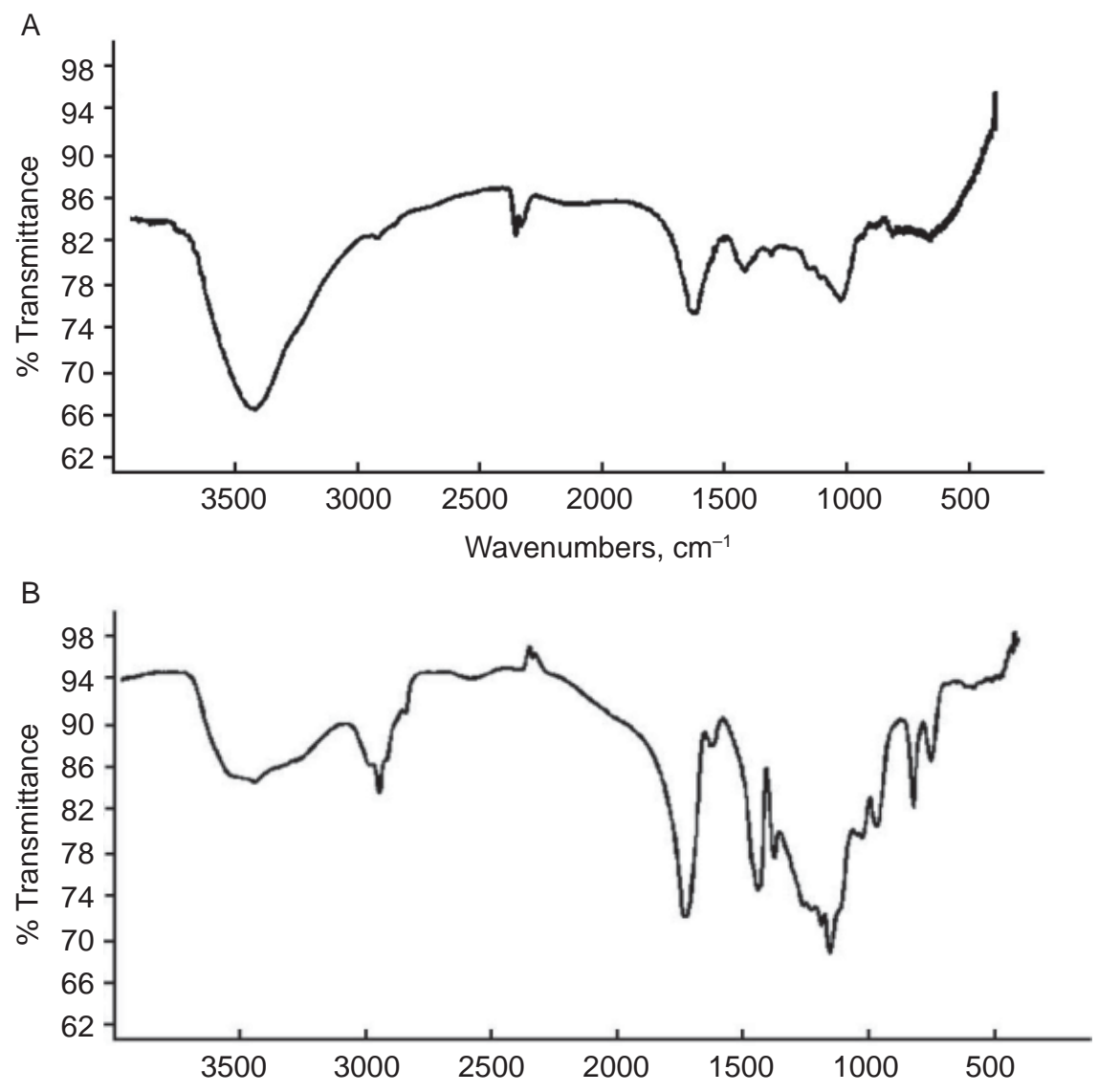

Wavenumbers, $\mathrm{cm}^{-1}$

C

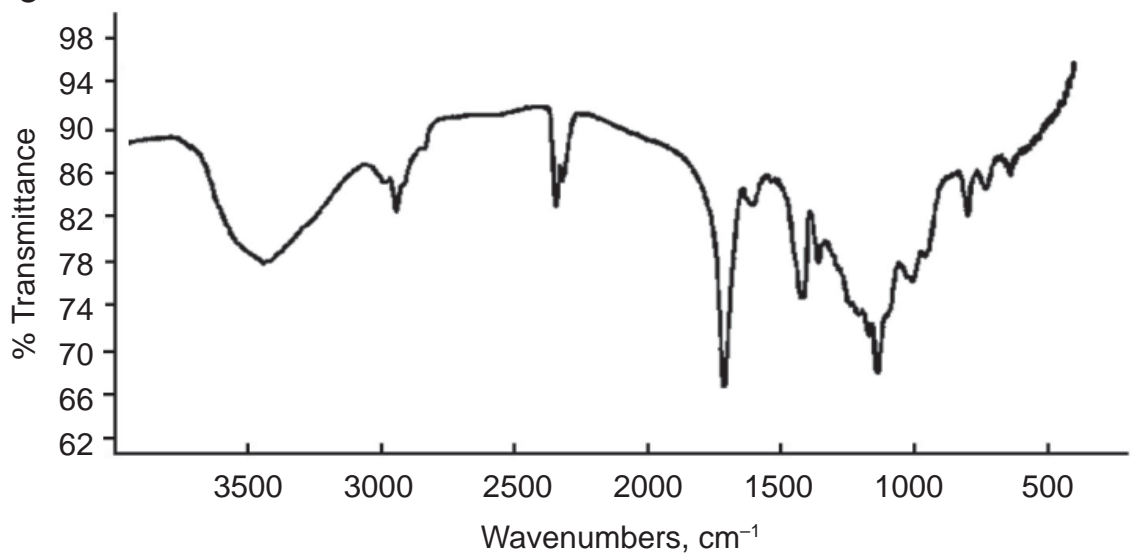

Fig. 1. FTIR spectra of A) calcium alginate, B) Mac, and C) calcium alginate and methacrylic acid complex 

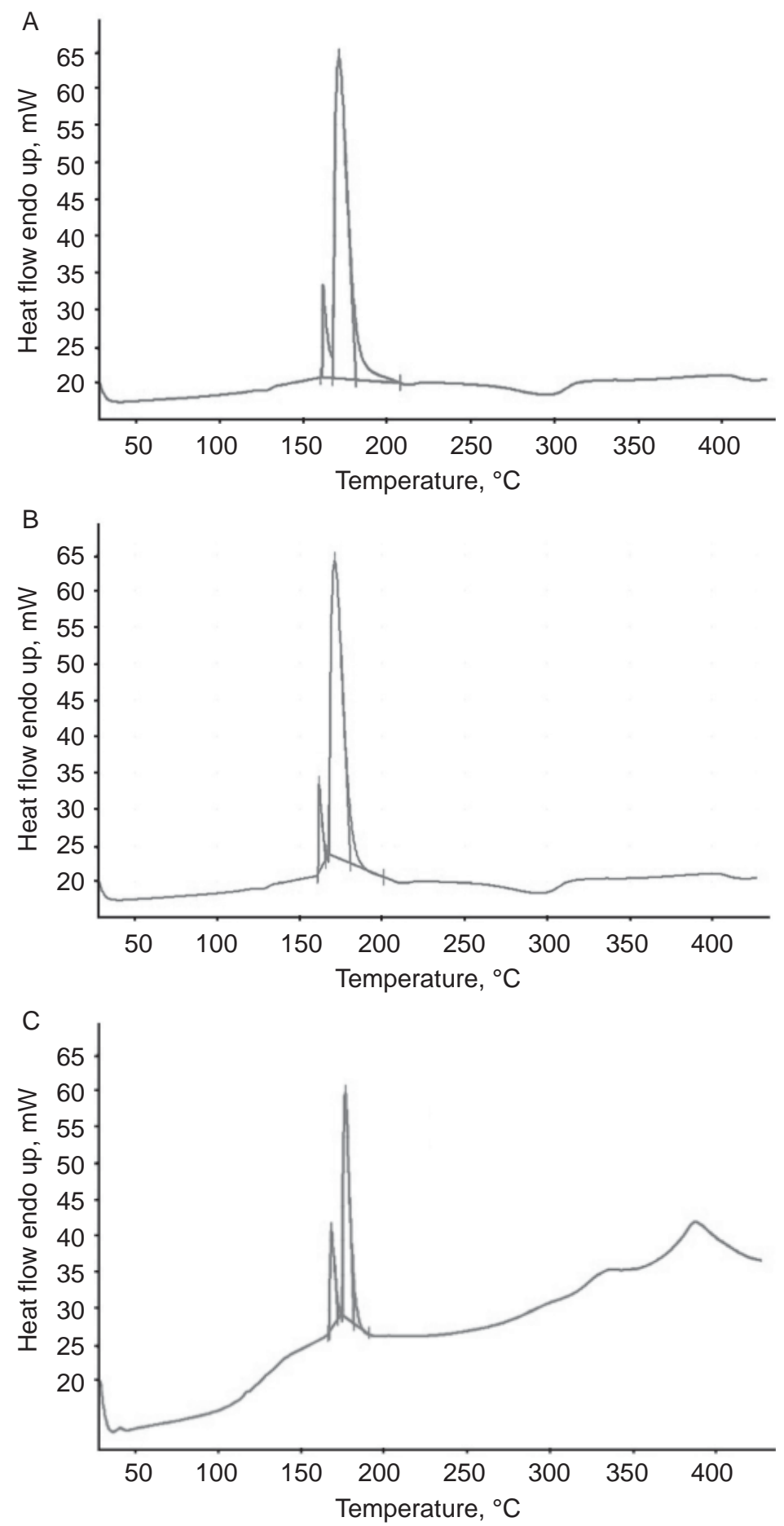

Fig. 2. DSC thermogram of A) calcium alginate, B) Mac, and C) calcium alginate and methacrylic acid complex 
$(\mathrm{P}<0.05)$ in appearance, texture, graininess, mouthfeel, and overall acceptability as compared to the control, whereas aroma, sourness, and aftertaste showed insignificant differences. The rigidity and hardness of the MAc-coated alginate beads were apparent during mastication (BURGAIN et al., 2011), suggesting the need to reduce the size of the beads.

Table 1. Consumer acceptance and preference of controls (blank orange juice and mayonnaise) and samples (orange juice and mayonnaise containing MAc-coated alginate beads)

\begin{tabular}{|c|c|c|c|c|c|c|c|c|}
\hline Products & Appearance & Aroma & Texture & Graininess & Sourness & Mouthfeel & Aftertaste & $\begin{array}{c}\text { Overall } \\
\text { acceptability }\end{array}$ \\
\hline $\begin{array}{l}\frac{\text { Control }}{\text { (Blank orange }} \\
\text { juice) }\end{array}$ & $\begin{array}{l}1.84 \pm \\
0.96^{\mathrm{a}}\end{array}$ & $\begin{array}{l}1.87 \pm \\
0.97^{\mathrm{a}}\end{array}$ & $\begin{array}{l}1.84 \pm \\
0.79^{\mathrm{a}}\end{array}$ & $\begin{array}{r}2.03 \pm \\
0.78^{\mathrm{a}}\end{array}$ & $\begin{array}{r}2.25 \pm \\
1.03^{\mathrm{a}}\end{array}$ & $\begin{array}{l}1.91 \pm \\
0.79^{\mathrm{a}}\end{array}$ & $\begin{array}{r}2.15 \pm \\
1.13^{\mathrm{a}}\end{array}$ & $\begin{array}{l}1.67 \pm \\
0.73^{\mathrm{a}}\end{array}$ \\
\hline $\begin{array}{l}\text { Sample } \\
\text { (Orange juice } \\
\text { containing } \\
\text { MAc-coated } \\
\text { alginate beads) }\end{array}$ & $\begin{array}{r}2.06 \pm \\
1.02^{\mathrm{a}}\end{array}$ & $\begin{array}{r}2.10 \pm \\
1.01^{\mathrm{a}}\end{array}$ & $\begin{array}{c}2.46 \pm \\
1.10^{\mathrm{b}}\end{array}$ & $\begin{array}{c}2.81 \pm \\
1.03^{\mathrm{b}}\end{array}$ & $\begin{array}{r}2.52 \pm \\
1.10^{\mathrm{a}}\end{array}$ & $\begin{array}{r}2.55 \pm \\
1.10^{\mathrm{b}}\end{array}$ & $\begin{array}{r}2.43 \pm \\
1.18^{\mathrm{a}}\end{array}$ & $\begin{array}{r}2.30 \pm \\
1.00^{\mathrm{b}}\end{array}$ \\
\hline$\frac{\text { Control }}{\text { (Blank mayonnaise) }}$ & $\begin{array}{r}2.20 \pm \\
1.02^{\mathrm{a}}\end{array}$ & $\begin{array}{r}2.43 \pm \\
1.07^{\mathrm{a}}\end{array}$ & $\begin{array}{r}2.21 \pm \\
1.19^{\mathrm{a}}\end{array}$ & $\begin{array}{r}2.56 \pm \\
1.24^{\mathrm{a}}\end{array}$ & $\begin{array}{l}2.53 \pm \\
1.17^{\mathrm{a}}\end{array}$ & $\begin{array}{r}2.30 \pm \\
1.24^{\mathrm{a}}\end{array}$ & $\begin{array}{r}2.59 \pm \\
1.20^{\mathrm{a}}\end{array}$ & $\begin{array}{r}2.14 \pm \\
1.17^{\mathrm{a}}\end{array}$ \\
\hline $\begin{array}{l}\text { Sample } \\
\text { (Mayonnaise } \\
\text { containing } \\
\text { MAc-coated } \\
\text { alginate beads) }\end{array}$ & $\begin{array}{r}2.82 \pm \\
1.36^{\mathrm{b}}\end{array}$ & $\begin{array}{r}2.72 \pm \\
1.22^{\mathrm{a}}\end{array}$ & $\begin{array}{c}2.89 \pm \\
1.46^{\mathrm{b}}\end{array}$ & $\begin{array}{c}3.39 \pm \\
1.44^{\mathrm{b}}\end{array}$ & $\begin{array}{r}2.82 \pm \\
1.28^{\mathrm{a}}\end{array}$ & $\begin{array}{c}2.96 \pm \\
1.54^{\mathrm{b}}\end{array}$ & $\begin{array}{r}2.90 \pm \\
1.32^{\mathrm{a}}\end{array}$ & $\begin{array}{r}2.84 \pm \\
1.42^{\mathrm{b}}\end{array}$ \\
\hline
\end{tabular}

Results are expressed as the mean \pm standard error; $n=100$. ${ }^{\text {ab }}$ Means with different lowercase superscript letters are significantly different $(\mathrm{P}<0.05)$.

* 7-point hedonic scale; 1=Like very much, 2=Like moderately, 3=Like slightly, 4=Neither like nor dislike, 5=Dislike slightly, 6=Dislike moderately, 7=Dislike very much

\subsection{Storage}

Lactobacilli cells survived better $(\mathrm{P}<0.05)$ at $4{ }^{\circ} \mathrm{C}$ with survivability of $41.36 \%$ compared to $27{ }^{\circ} \mathrm{C}$ with $25.94 \%$ (Table 2). This may be due to the lower activities of cells at lower temperatures, while higher temperatures promote metabolic and cellular activity leading to uncontrolled growth, "overacidification" and the maximum usage of nutrients stored in the cells (DESAI, 2008). The viability of encapsulated lactobacilli cells in orange juice and heattreated orange juice declined weekly $(\mathrm{P}<0.05)$ at $4{ }^{\circ} \mathrm{C}$ with absence of growth after 8 wk and $6 \mathrm{wk}$, respectively. Heat-treated orange juice and mayonnaise showed a higher log reduction $(\mathrm{P}<0.05)$ compared to non-heat-treated samples, suggesting that lactobacilli cells were weakened during heat treatment. Although our DSC data demonstrated that calcium alginate and MAc beads were heat stable, the heat treatment could cause structural changes to the beads, thus reducing its protective effects against increasing temperatures (CHEN et al., 2007). In addition, $\mathrm{pH}$ changes were insignificant and the $\mathrm{pH}$ was maintained in all products throughout storage, indicating that the encapsulated cells and their metabolites did not diffuse out from the beads into the exterior environment. 


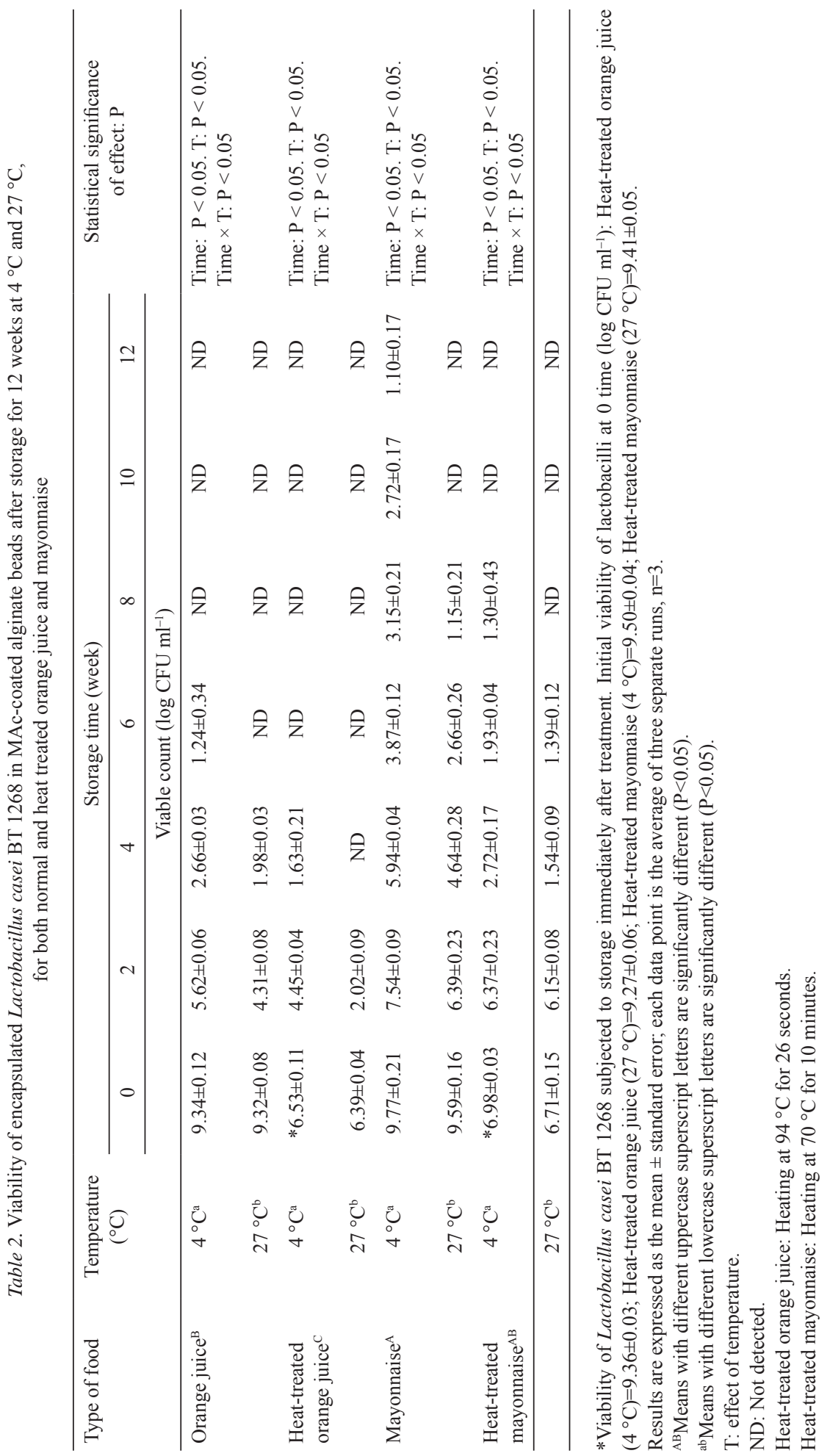


On the other hand, the viable counts dropped remarkably at the storage temperature of $27{ }^{\circ} \mathrm{C}$, where no growth after $6 \mathrm{wk}$ for orange juice and $4 \mathrm{wk}$ for heat-treated orange juice could be detected. The survival of lactobacilli cells in mayonnaise was higher than that in orange juice $(\mathrm{P}<0.05)$, where growth was observed after $12 \mathrm{wk}$ for normal mayonnaise and $8 \mathrm{wk}$ for heat-treated mayonnaise stored at $4{ }^{\circ} \mathrm{C}$. No growth was observed after $10 \mathrm{wk}$ and $8 \mathrm{wk}$ for both mayonnaise and heat-treated mayonnaise stored at $27{ }^{\circ} \mathrm{C}$, respectively. In general, viability could be sustained longer in a colloidal high acidic food compared to the liquid counterpart, mainly attributed to the diffusion of acidity into the encapsulated matrix. We have previously demonstrated that MAc-coated alginate beads may prevent cell release in acidic media and could protect cells under simulated gastric conditions at $\mathrm{pH} 2$ for 90 min (ThAm et al., 2014). However, under prolonged storage, subsequent diffusion of acidic media into the beads could occur leading to reduced cell viability (IBEKWE et al., 2006).

\section{Conclusions}

Alginate beads coated with MAc could exhibit appropriate cell protection in high acidic foods. Optimization of coating materials may produce higher survival rates and cell viability over storage. Consumer preference showed that the presence of beads could be felt, leading to a reduced acceptance score. The production of beads as nano-size particles may alleviate this problem.

This work was financially supported by the short term grant (304/PTEKIND/6312056) and Graduate Assistant scheme provided by the Universiti Sains Malaysia.

\section{References}

Bianco, G., Soldi, M.S., Pinheiro, E.A., Pires, A.T.N., Gehlen, M.H. \& Soldi, V. (2003): Thermal stability of poly(N-vinyl-2-pyrrolidone-co-methacrylic acid) copolymers in inert atmosphere. Polym. Degrad. Stabil., 80, $567-574$.

Burgain, J., Gaiani, C., Linder, M. \& Scher, J. (2011): Encapsulation of probiotic living cells: From laboratory scale to industrial applications. J. Fd Engng, 104, 467-483.

Chen, M.J., Chen, K.N. \& Kuo, Y.T. (2007): Optimal thermotolerance of Bifidobacterium bifidum in gellan-alginate microparticles. Biotechnol. Bioengng, 98, 411-419.

Desai, A. (2008): Strain identification, viability and probiotics properties of Lactobacillus casei (Academic Dissertation. Victoria University). Retrieved from http://vuir.vu.edu.au/1932/1/desai.pdf. 228 pages.

Fung, W.Y., Yuen, K.H. \& Liong, M.T. (2011): Agrowaste-based nanofibers as a probiotic encapsulant: fabrication and characterization. J. Agr. Fd Chem., 59, 8140-8147.

Girhepunje, K.M., Krishnapilllai, Pal, R.S., Gevariya, H.B. \& Thirumoorthy, N. (2010): Celecoxib loaded microbeads: A targeted drug delivery for colorectal cancer. Int. J. Curr. Pharm. Res., 2(1), 46-55.

Gulrez, S.K.H., Al-Assaf, S. \& Phillips, G.O. (2011): Hydrogels: methods of preparation, characterization and applications. -in:. CARPI, A. (Ed.) Progress in molecular and environmental bioengineering - from analysis and modeling to technology applications. InTech, Croatia, pp. 117-150.

Ibekwe, V.C., Fadda, H M., Parsons, G.E. \& Basit, A.W. (2006): A comparative in vitro assessment of the drug release performance of $\mathrm{pH}$-responsive polymers for ileo-colonic delivery. Int. J. Pharm., 308, 52-60.

Khalil, A.H. \& Mansour, E.H. (1998): Alginate encapsulated bifidobacteria survival in mayonnaise. J. Fd Sci., 64, $702-705$.

Krasaekoopt, W. \& Kitsawad, K. (2010): Sensory characteristics and consumer acceptance of fruit juice containing probiotics beads in Thailand. AU J. Technol., 14(1), 33-38. 
Liong, M.T. \& ShaH, N.P. (2005): Production of organic acids from fermentation of mannitol, FOS and inulin by a cholesterol removing Lactobacillus acidophilus strain. J. Appl. Microbiol., 99, 783-793.

Liong, M.T., DunsheA, F.R. \& ShAN N.P. (2007): Effects of a synbiotic containing Lactobacillus acidophilus ATCC 4962 on plasma lipid profiles and morphology of erythrocytes in hypercholesterolaemic pigs on high- and low-fat diets. Brit. J. Nutr., 98, 736-744.

Mladenovska, K., Cruaud, O., Richomme, P., Belamie, E., Raicki, R.S., Venier-Julienne, M.C., Popovski, E., Benoit, J.P. \& Goracinova, K. (2007): 5-ASA loaded chitosan-Ca-alginate microparticles: Preparation and physicochemical characterization. Int. J. Pharm., 345, 59-69.

Moustafine, R.I., Bodrov, A.V., Kemenova, V.A., Rombaut, P. \& Van Den Mooter, G. (2010): Drug release modification by interpolymer interaction between countercharged types of Eudragit RL 30 D and FS 30 D in double-layer films. Int. J. Pharm., (2012) 439(1-2), 17-21.

Rufino, E.S. \& Monteiro, E.E.C. (2003): Infrared study on methyl methacrylate-methacrylic acid copolymers. Polymer, 44, 7189-7198.

Sarmento, B., Ferreira, D., Veiga, F. \& Nio Ribeiro, A. (2006): Characterization of insulin-loaded alginate nanoparticles produced by ionotropic pre-gelation through DSC and FTIR studies. Carbohyd. Polym., 66, $1-7$.

Sibeko, B., Choonara, Y.E., Du Toit, L.C., Modi, G., Naidoo, D., Khan, R.A., Kumar, P., Ndesendo, V.M.K., Iyuke, S.E. \& Pillay, V. (2012): Composite polylactic-methacrylic acid copolymer nanoparticles for the delivery of methotrexate. J. Drug Deliv. doi:10.1155/2012/579629

Sultana, K., Godward, G., Reynolds, N., Arumugaswamy, R., Peiris, P. \& Kailasapathy, K. (2000): Encapsulation of probiotic bacteria with alginate-starch and evaluation of survival in simulated gastrointestinal conditions and in yoghurt. Int. J. Fd Microbiol., 62, 47-55.

Tнам, C.S.C., Рен, K.K. \& Liong, M.T. (2014): Survivability of lactobacilli cells upon coating with methacrylic acid copolymers. Acta Alimentaria , 43, [In-press]

Walkuing-Ribeiro, M., Noci, F., Cronin, D.A., Lyng, J.G. \& Morgan, D.J. (2009): Shelf life and sensory evaluation of orange juice after exposure to thermosonication and pulsed electric fields. Fd Bioprod. Process., 87, $102-107$. 